\title{
Nutrition Physiology of Juveniles Individuals of Pumpkinseed Lepomis gibbosus (Linnaeus, 1758) from the Samara Bay (Ukraine)
}

\author{
O.S. Nesterenko, O.M. Marenkov*, Ye.S. Pylypenko
}

Scientific Research Laboratory of Hydrobiology, Ichthyology and Radiobiology of the Scientific Research Institute of Biology of the Oles Honchar Dnipro National University, Dnipro, Ukraine

*Corresponding author: gidrobions@gmail.com

Keywords: pumpkinseed, Lepomis gibbosus, histology, digestive system, Zaporizhzhia (Dnipro) reservoir

\begin{abstract}
The article presents the results of studies physiology of nutrition of juveniles individuals of pumpkinseed Lepomis gibbosus (Linnaeus, 1758) from the Zaporizhzhia (Dnipro) reservoir. Histological structure, morphometric parameters of digestive system and nutrition biology were investigated. The material for work were collected during scientific research in June-July 20162017. The ichthyological sampling was carried out in the Samara Bay of the Zaporizhzhia (Dnipro) reservoir. Researches of structure of digestive system were conducted using histological methods, researches of nutrition were conducted using ichthyological and hydrobiological methods. The height of the intestinal epithelium of the pumpkinseed `s juveniles varies from 15.5 microns to 51.9 microns and on average is $32.59 \pm 9.03$ microns, the area of secretory goblet cells of the intestine reaches $198.61 \pm 36.55 \mu \mathrm{m}^{2}$. It was revealed that the pumkinseed's juveniles only feed on phytoplankton. Research results can be useful for further study on the fish nutrition, especially sexual matured. Also, nutrition studies can help to find biomeliorative methods to combat the pumpkinseed, because the species is in competition with industrially valuable species of fish for fodder.
\end{abstract}

\section{Introduction}

The pumpkinseed is the one of the newest alien species of Ukrainian reservoirs, which is rapidly expanding its range and inhabits new reservoirs of our country [1]. The pumpkinseed Lepomis gibbosus (Linnaeus, 1758), a representative of the American faunal complex, belongs to the family Centrarchidae to the order Perciformes. The natural range of pumpkinseed is the freshwater reservoirs of North America from the Great Lakes to Florida [2, 3, 4, 5]. In the Zaporizhzhia (Dnipro) reservoir the pumpkinseed is known as the alien species [6]. To date, this species has become well acclimated and has expanded its habitat in the reservoirs of Dnipropetrovsk region $[7,8]$.

The spread of alien fish, including the pumpkinseed, is one of the topical issues of ichthyological science. Because it is a competitor for fodder resources to the native species of fish and is capable of damaging the fishery by eating eggs, larvae, juvenile form of valuable species of fish [8]. The biology and ecology of this species in the Dnieper reservoirs has not been sufficiently studied. To date, little-known features of feeding pumpkinseed in the Zaporizhzhia (Dnipro) reservoir and features of the structure of its digestive system. Therefore, the study of the physiological aspects and spectrum of nutrition of hydrobionts is important and has applied value [9].

\section{Materials and Methods}

The object of the study were two-month-old juveniles individuals of pumpkinseed Lepomis gibbosus (Linnaeus, 1758). One hundred goblet cells and their nuclei of the intestinal epithelium were analyzed and measured during the study.

The material for work were collected during scientific research in June-July 2016-2017. The ichthyological sampling was carried out in the Samara Bay of the Zaporizhzhia (Dnipro) reservoir. 
The fish were caught at observation points located in the Samara Bay (Novoselivka village 48.57354 N, 35.23509 E).

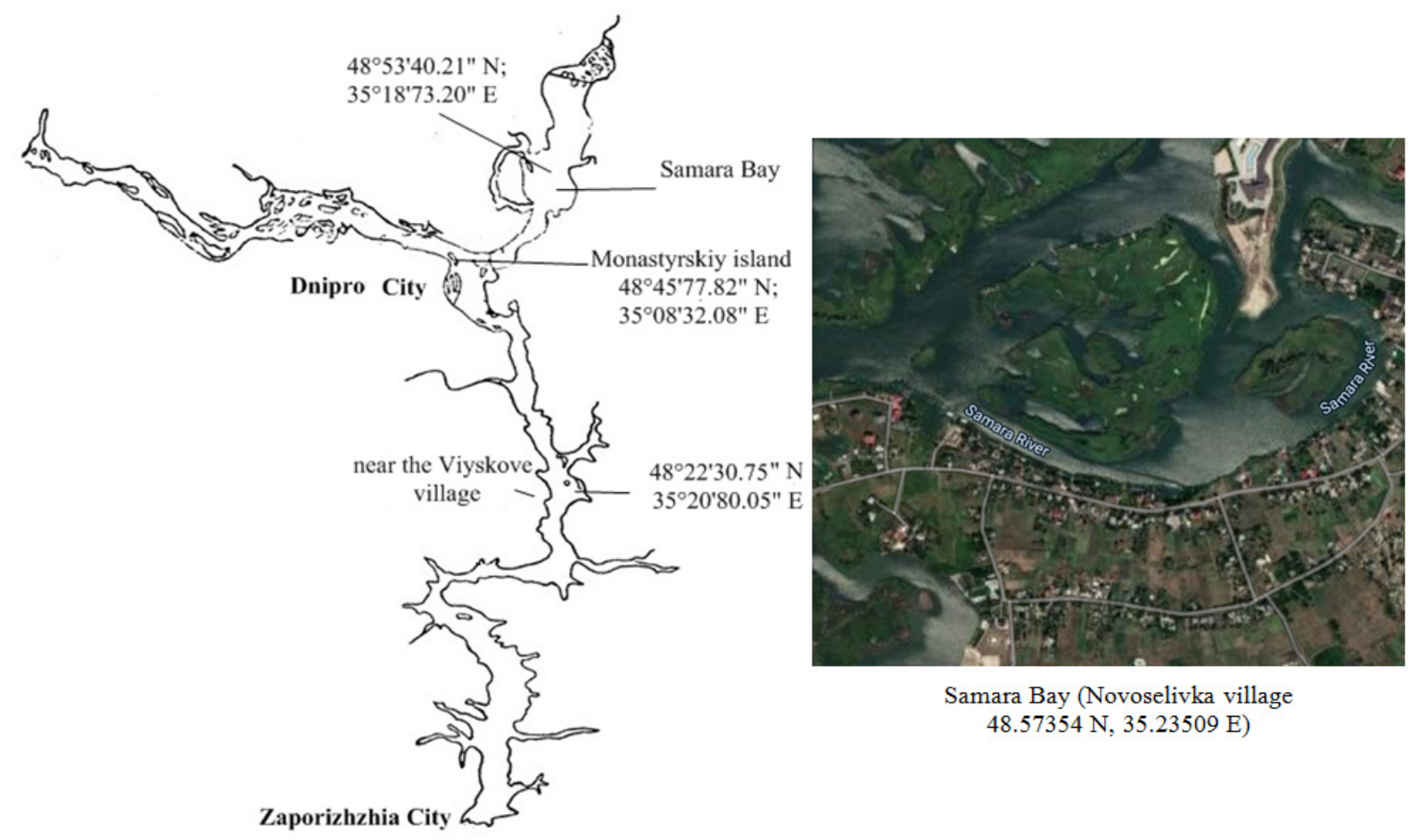

Figure 1. Physico-geographical position of the Zaporizhzhia (Dnipro) reservoir ( $\left.48^{\circ} 08^{\prime} 09^{\prime \prime} \mathrm{N} 35^{\circ} 07^{\prime} 43^{\prime \prime} \mathrm{E}\right)$.

The research was conducted on the basis of permits for special use of aquatic bioresources. The fish were caught in the shallow waters of Samara Bay in the third decade of August. Catching of fish were carried out with a 10-meter 1-m-high cotton fabric made of mill gas No. 7 and a 4-mmdiameter nylon dell. For pumkinseed's juveniles length measurements were made with an accuracy of up to $1 \mathrm{~mm}$, masses of individuals - with an accuracy of $0.01 \mathrm{~g}[11,12]$. The hystological analysis of fish tissues and nutrition research were carried out in accordance with the classical hystological and ichthyological methods and was performed according to "Provisions for the use of animals in biomedical experiments" $[11,13,14,15]$.

Histological sections of the tissues of the digestive system of the pumpkinseed were made on a microtome "Microm HM 352". Sections were stained with hematoxylin-eosin. The morphometric parameters of cells in different departments of the digestive tract were measured using digital software of camera "Sciencelab T500 5,17M" which is attached to the microscope. The study of the spectrum of nutrition was performed with the aid of a food lump analysis.

Statistical data processing was carried out by generally accepted methods using the software package Statistica 8.0 (StatSoft Inc., USA). All results are given as the mean value \pm standard deviation (SD).

\section{Results and Discussion}

Nutrition research. Thirty copies of two-month-old juveniles individuals of pumpkinseed we analyzed with the following parameters: $\mathrm{L}=3.96 \pm 0.06 \mathrm{~cm}, 1=3.16 \pm 0,06 \mathrm{~cm}, \mathrm{~m}=0,83 \pm 0,05 \mathrm{~g}$. Investigating the contents of the gastrointestinal tracts of pumpkinseed, we discovered freshwater algae that belonged to four classes: Bacillariophyceae, Cyanophyta, Chlorophyta and Euglenophyceae. It was found that the largest number of algae belonged to the Diatom group (Bacillariophyceae) $52 \%$ (20 genuses) of the total number of identified algae, in the second place freshwater algae of the Green group (Chlorophyta) $25 \%$ (10 genuses), the next group is Blue-green algae (Cyanophyta) $18 \%$ (7 genuses), the smallest number of species - Euglenophyceae $5 \%$ (2 genuses). In total, in each group it was received the following percentage: 
The class Bacillariophyceae was dominated by Asterionella $-19.58 \pm 3.29 \%$, Navicula$14.74 \pm 2.15 \%$ and Fragilaria $-13.83 \pm 2.36 \%$ (Fig. 1).

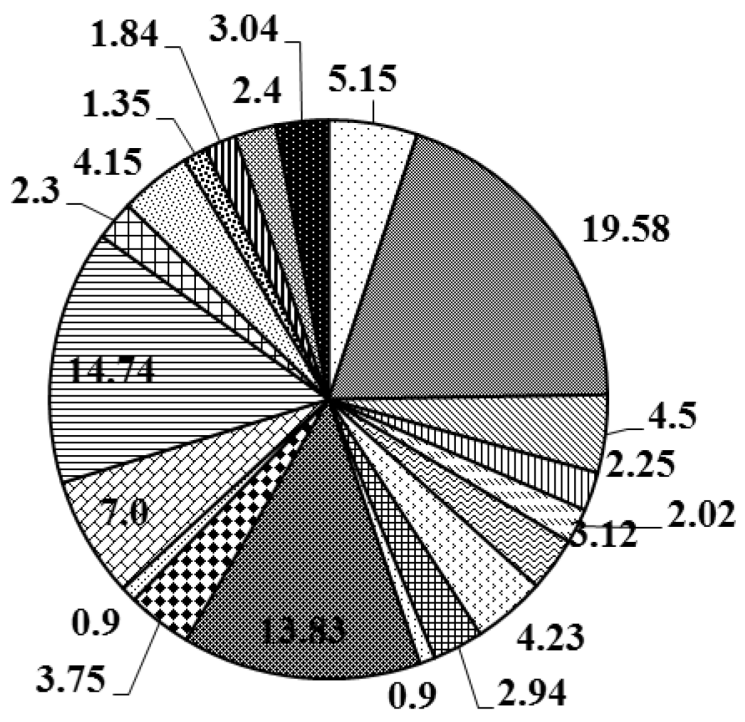

\begin{tabular}{|c|}
\hline 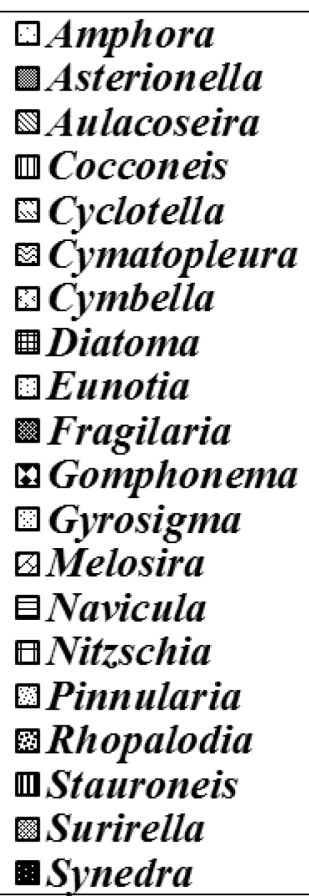 \\
\hline
\end{tabular}

Figure 1. Percentage of algae of Bacillariophyceae

Other $52 \%$ of algae were presented by Amphora, Aulacoseira, Cocconeis, Cyclotella, Cymatopleura, Cymbella, Diatoma, Eunotia, Gomphonema, Gyrosigma, Melosira, Nitzschia, Pinnularia, Rhopalodia, Stauroneis, Surirella, Synedra.

The class Chlorophyta was dominated by Ulothrix $-23.69 \pm 3.20 \%$ and Cladophora$20.07 \pm 3.46 \%$ (Fig. 2).

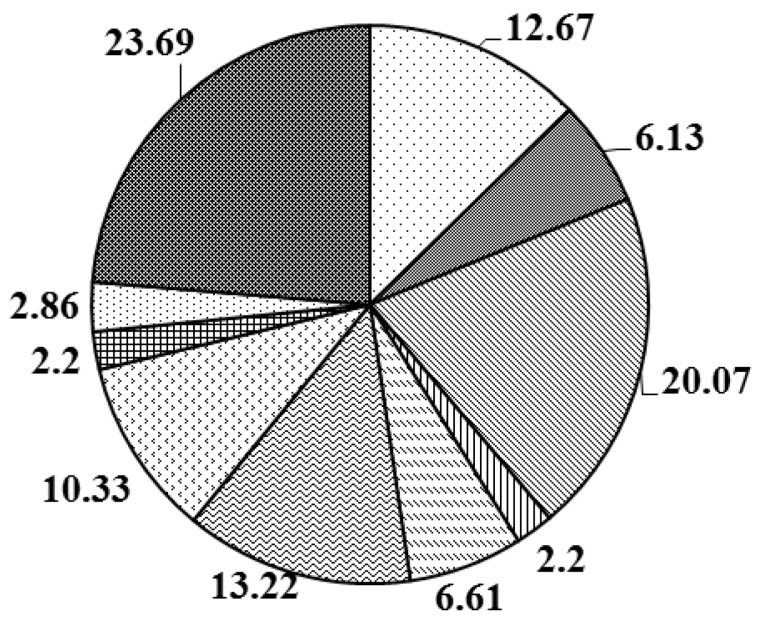

\begin{tabular}{|c|}
\hline$\square$ Ankistrodesmus \\
\hline$\square$ Chlorella \\
\hline$\$$ Cladophora \\
\hline ⿴囗十) Closterium \\
\hline ๑Coenochloris \\
\hline Gonium \\
\hline Đocystis \\
\hline 田Pediastrum \\
\hline$\square$ Scenedesmus \\
\hline 圆Uloth rix \\
\hline
\end{tabular}

Figure 2. Percentage of algae of Chlorophyta

Other $56 \%$ were presented by Ankistrodesmus, Chlorella, Closterium, Coenochloris, Gonium, Oocystis, Pediastrum and Scenedesmus.

The class Cyanophyta was dominated by Pseudoholopedia $-50.79 \pm 8.23 \%$, Microcystis $26.08 \pm 4.52 \%$ and Oscillatoria $-14.68 \pm 2.60 \%$ (Fig. 3). 


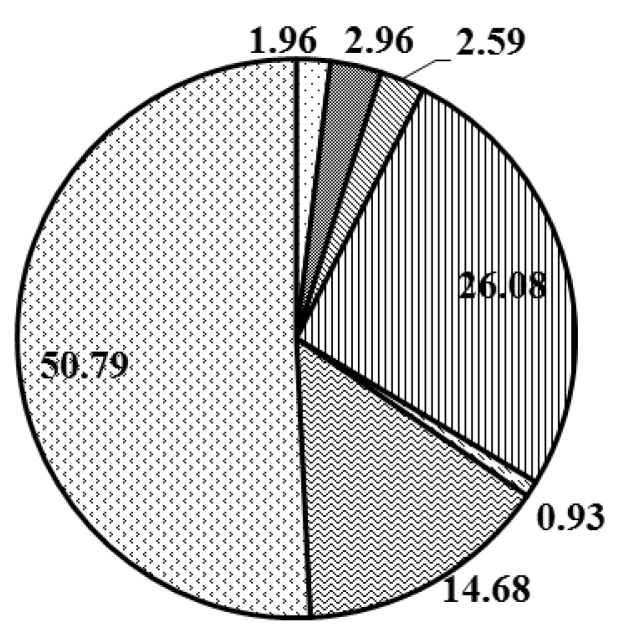

\begin{tabular}{|l|}
\hline$\square$ Anabaena \\
$\square$ Gloeocapsa \\
هMerismopedia \\
$\square$ Microcystis \\
$\square$ Phormidium
\end{tabular}

Figure 2. Percentage of algae of Cyanophyta

Other 8,5\% were presented by Anabaena, Gloeocapsa, Merismopedia, Phormidium. Class Euglenophyceae: Evglena - $33.33 \pm 5.33 \%$, Trachelomonas $-66.67 \pm 12.33 \%$.

According to Eselevich and Kozlova [16] sunfish larvae first feed on ciliates and small rotifers. The species composition of organisms consumed by sunfish varies depending on the size of the fish. Scientists have noted that fish fry with a size of less than $30 \mathrm{~mm}$ are potentially consumers of phytoplankton $[17,18]$ and when they reach a size above $30 \mathrm{~mm}$, they switch to feeding on other groups of aquatic organisms. The authors $[16,19]$ indicate that individuals of the $2-2.5 \mathrm{~cm}$ sunfish consume crustaceans, $8 \mathrm{~cm}$ juveniles feed on insects, and individuals larger than $10 \mathrm{~cm}$ feed on small fish, tadpoles and mollusks. Probably obtained data on the nutrition of small fry of sunfish with phytoplankton is a food feature in the Samara Bay.

Histological research. During the study of histological structure of digestive system of pumpkinseed we have analyzed one hundred goblet cells and their nuclei of the intestinal epithelium were analyzed and measured.

The digestive system of the pumpkinseed is represented by the oral cavity, which smoothly turns into the pharynx. In the depth of the pharynx, a short esophagus begins, which almost immediately turns into the stomach (gaster). The intestine follows the stomach, and it is slightly differentiated into thin and thick sections. The rectum opens outward with an anus.

The intestinal epithelium of fish performs trophic and secretory functions, as it takes part in digestion processes. In the intestine of the pumpkinseed, besides the fermentation, nutrients are absorbed. The most intensive absorption occurs in the posterior part, the large intestine. The large intestine mainly carries out an absorption function, and water in the chymus is intensively absorbed in this section, while in other sections water, conversely, is secreted into the lumen of the intestinal tube, maintaining the liquid state of the chymus. This is facilitated by the folded structure of its walls, the presence of villiferous outgrowths with capillaries and lymphatic vessels and the presence of cells secreting mucus.

The intestine of the pumpkinseed, like other bony fishes` one, is covered with a monostichous monolayer prismatic epithelium, which can also have outgrowths in the form of microvilli on its apical surface. Due to this, it is called a monolayer monostichous prismatic microvillous epithelium. The height of the epithelium of the intestine of pumpkinseed's fry varies from 15.5 microns to 51.9 microns and on average it is $32.59 \pm 9.03$ microns.

Epithelial cells of the intestine are polar. The nuclei of epithelial cells are located closer to the basal membrane and are almost at the same level forming one row. The growth cells are not scattered throughout the epithelial lining, as in other types of epithelium, but are concentrated in special indentations of the folds of the intestinal mucosa, where regeneration of the intestinal epithelium occurs (Fig. 4). Cycling cells are gradually pushed upwards through the intestinal folds by new cellular generation, replacing aging cells. Old and damaged epithelial cells gradually slough 
off from the upper parts of the folds of the formation. The connection between the cells of the intestinal epithelium and the basal membrane is weak.

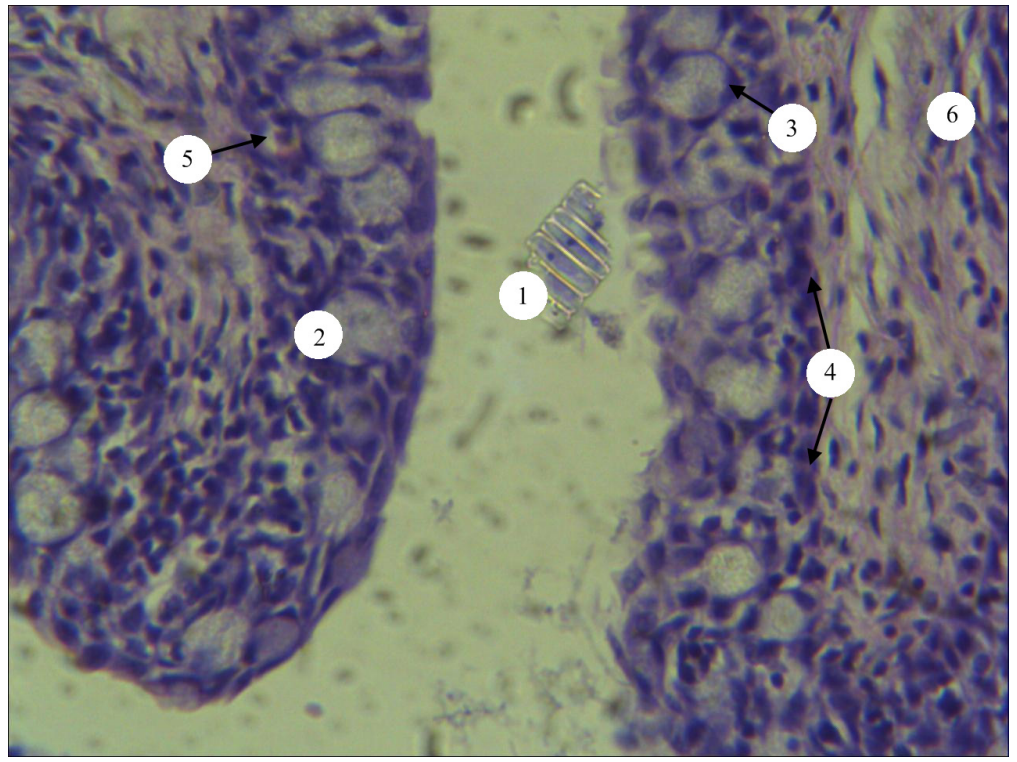

Figure 4. Epithelial folds of the intestine of the pumpkinseed: 1 - fragment of the food bolus, diatom residue, 2 - goblet epitheliocytes, 3 - nucleus of the goblet cell, 4 - basal membrane, 5 - lumen of the blood vessel with erythrocyte. Preparation of O.N. Marenkov. Hematoxylin-eosin. 400x.

As epitheliocytes move through the intestinal folds, they differentiate in two directions: into a normal cell of the intestinal epithelium or into a unicellular glandular cell called the goblet cell. In juveniles of pumpkinseed, the area of secretory goblet cells of the intestine reaches $198.61 \pm 36.55$ $\mu \mathrm{m}^{2}$. In the epithelial lining of the thin and thick sections of the intestine of fish, numerous goblet cells are unicellular glands that secrete mucus and thereby protect the intestinal membrane from various mechanical or chemical damages.

Sickle-shaped flattened nuclei of goblet cells, shifted to the basal membrane contain a large amount of chromatin. The cross-sectional area of the nuclei of the mucous cells of the pumpkinseed's juveniles reaches on average $11.29 \pm 2.89 \mu \mathrm{m}^{2}$. There is a large drop of secretion in the cytoplasm of these cells and it gradually shifts to the apical end of the secretory cell, thus cell acquires specific goblet shape. As goblet cells have significant secretory activity, the endoplasmic reticulum and the Golgi apparatus are well developed. Organelles are located in a cage between the nucleus and its apical end.

Villi of the mucous membrane has a fingerlike shape. Monolayer prismatic epithelium with microvilli covers the surface of the villi. The basis of the villi is formed by the protuberances of the plate of the mucous membrane. The cells of the epithelium are high; they have elongated nuclei located close to each other. They are large enough and resemble a stockade, continuously passes below the middle of the cells along the entire length of the villi. The lower edge of the cells turns into the basal membrane and it is not clearly discernible. Between the villi there are intestinal crypts formed by the epithelium, which passes from the villi into its own plate. Under the crypts, there is a muscular plate of the mucosa, behind which the submucosa is located, formed by a loose connective tissue (Fig. 5). The muscular membrane consists of two layers: the inner anular and the outer longitudinal. Outer serous membrane is a thin connective tissue layer covered with mesothelium. 


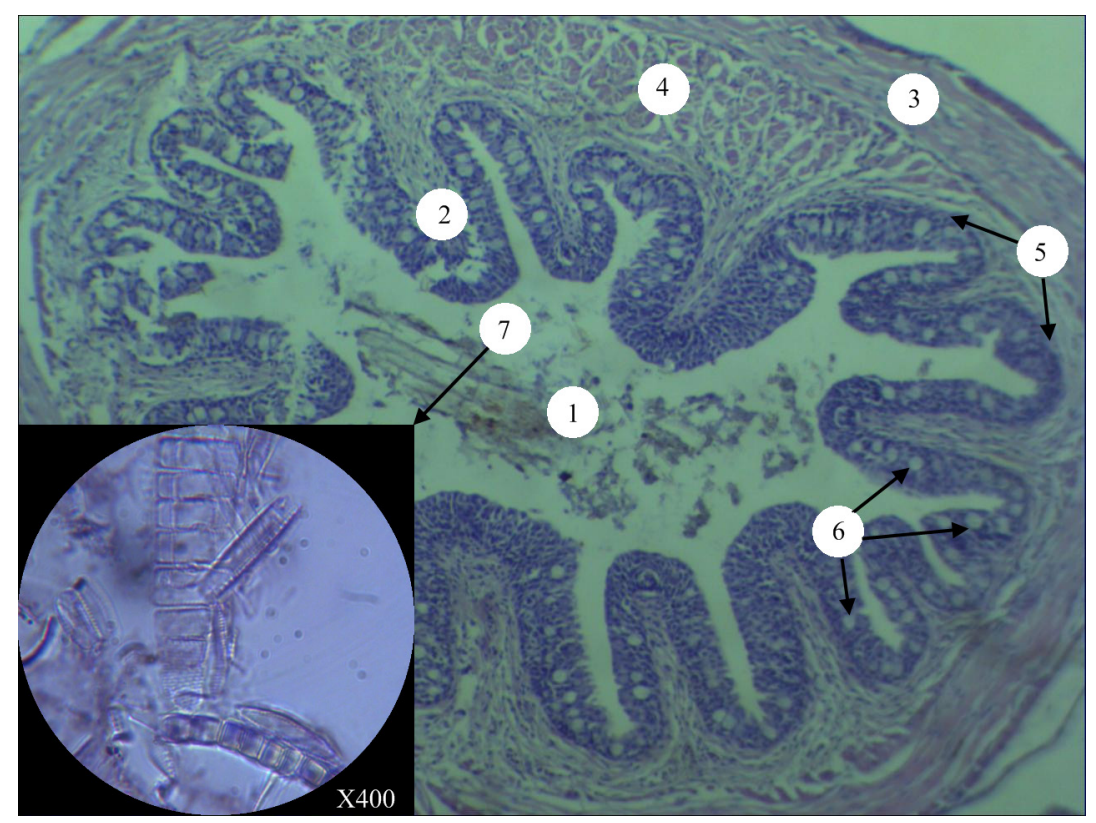

Figure 5. Transverse section of the intestine of the pumpkinseed: 1 - lumen of the intestine, 2 villi of the intestine, 3 - unstriated muscles, 4 - connective tissue, 5 - basal membrane, 6 - goblet cells, 7 - intestinal contents, shells of diatoms. Preparation of O.N. Marenkov. Hematoxylin-eosin, 150x.

On the surface of the cells, there is thin border with microvilli, which on the preparation looks like an unstructured pink cuticle. Between the epithelial cells in some places, goblet cells are visible. They look like light bubbles. The cruses of these cells go into the epithelium, wedging in between the neighboring cells. The flattened nuclei of goblet cells are located at their bases.

The polarity of the cells of the intestinal epithelium of the pumpkinseed is strongly obvious. A set of microvilli or a specific brush border is well developed. The length of the microvilli of the goblet epitheliocytes of the pumpkinseed is in the range from 0.5 to $2.8 \mu \mathrm{m}$. The presence of microvilli increases the surface area of the epithelial cell by more than 30 times, since each microvilli has a diameter of 70-80 nm, their total number per 1 square millimeter of the intestine area averages 150 million units. Microvilli play an important role in the process of parietal digestion: they adsorb the various substances concentrating at the base of the surface, which by pinocytosis enter the cytoplasm of the cell.

The formation of microvilli in the cells of the intestinal epithelium of the pumpkinseed is observed even in the bases of the folds, where their number per cell on average reaches 220 units. As the epithelial cells move towards the top of the intestinal fold, the number of microvilli increases and in its middle part of the intestinal fold reaches 2300 units. As the epithelial cells move toward the apex of the intestinal fold, the number of microvilli decreases.

\section{Conclusions}

Studies of the nutrition of pumpkinseed fry give grounds for future research, because in comparison with other studies in different habitats, the nutrition spectrum of fish fry of this species differs. In the conditions of the Samara Bay the consumption of fry exclusively by phytoplankton is noted.

Histological studies of the digestive system of the pumpkinseed fry are performed for the first time. The obtained data allow for model experiments with chemicals, heavy metals, etc., that is opportunities for comparison with the normal histological structure of the secretory tissues of the digestive system. 


\section{References}

[1] V.L. Bulakhov, R.O. Novitskiy, O.Y. Pakhomov, O.A. Hristov. Biological diversity of Ukraine. Dnipropetrovsk region. Cyclostomes (Cyclostomata). Fish (Pisces). Dnipropetrovsk University Press, Dnipropetrovsk, 2008. (in Ukrainian).

[2] E. Fobert, G. Zięba, L. Vilizzi, M. J. Godard, M. G. Fox, S. Stakènas, G. H. Copp. Predicting non-native fish dispersal under conditions of climate change: case study in England of dispersal and establishment of pumpkinseed Lepomis gibbosus in a floodplain pond. Ecology of Freshwater Fish, 22(1) (2013) 106-116.

[3] W. B. Skott, E. J. Grossman. Freshwater fishes of Canada. Bulletin 184. Fish. Res.BoardCan., Ottava, 1973.

[4] S. Stakènas, L. Vilizzi, G. H. Copp. Habitat use, home range, movements and interactions of introduced Lepomis gibbosus and native Salmo trutta in a small stream of Southern England. Ecology of Freshwater Fish, 22(2) (2013) 202-215.

[5] J. Tomeček, V. Kováč, S. Katina. Ontogenetic variability in external morphology of native (Canadian) and non-native (Slovak) populations of pumpkinseed Lepomis gibbosus (Linnaeus 1758). Journal of Applied Ichthyology, 21(4) (2005) 335-344.

[6] E. V. Fedonenko, O. N. Marenkov. Spreading, spatial distribution, and morphometric characteristics of the pumpkinseed sunfish Lepomis gibbosus (Centrarchidae, Perciformes) in the Zaporozhye Reservoir. Russian journal of biological invasions, 4(3) (2013) 194-199.

[7] O. Marenkov. Ichthyofauna of the Zaporizhia Nuclear Power Plant cooling pond (Enerhodar, Ukraine) and its biomeliorative significance. Ukrainian Journal of Ecology, 8(2) (2018) 140.

[8] O. Marenkov, O. Nesterenko. Estimation of physiological and biological indices and consequences of biological invasion of the pumpkinseed Lepomis gibbosus (Linnaeus, 1758) in the Zaporizke Reservoir, Ukraine. World Scientific News, 95 (2018) 27.

[9] Y. S. Voronkova, O. M. Marenkov, K. K. Holoborodko. Liver antioxidant system of the Prussian carp and pumpkinseed as response to the environmental change. Ukrainian Journal of Ecology, 8(1) (2018) 749-754.

[10] O. N. Marenkov. Abundance and biomass estimation of this summer individuals of alien fish species in Zaporizke reservoir. Ukrainian Journal of Ecology, 8(1) (2018) 92-96.

[11] Methods of Hydroecological Surveys of Surface Waters. Ed. V. D. Romanenko (Kyiv: LOGOS, 2006) 408 p. (in Ukrainian)

[12] Methods for fish biology. Ed. by Carl B. Schreck and Peter B. Moyle. (Bethesda, Maryland, USA, 1990) $685 \mathrm{p}$.

[13] S. Mumford, J. Heidel, C. Smith, J. Morrison, B. MacConnell, V. Blazer. Fish histology and histopathology. US Fish and Wildlife National Conservation Training Center, Amerika Serikat, 2007.

[14] E. V. Mikodina, M. A. Sedova, D. A. Chmilevskiy, A. E. Mikulin, S. V. Pianova, O.G. Poluektova. Histology for ichthyologists: Experience and recommendations, Moscow, 2009.

[15] Medical ethics and human rights: the provisions for the use of animals in biomedical experiments. Exp Clin Physiol Biochem, 2003, 22(2) (2003) 108-109. (In Ukrainian).

[16] V. L. Elesevich, F. Sh. Kozlova, Solnechnyy okun Dnepra I polucheniye ot nego potomstva v usloviyakh akvariuma. Gidrobiologicheskiy zhurnal, 11(3) (1974) 101-105.

[17] I. Ferrari, A. R. Chieregato, Feeding habits of juvenile stages of Sparus auratus L., Dicentrarchus labrax L. and Mugilidae in a brackish embayment of the Po River delta. Aquaculture, 25(2-3) (1981) 243-257.

[18] J. M. Hanson, S. U. Qadri, Feeding ecology of age 0 pumpkinseed (Lepomis gibbosus) and black crappie (Pomoxis nigromaculatus) in the Ottawa River. Canadian journal of zoology, 62(4) (1984) 613-621.

[19] A. Ya. Shcherbuha, Fauna Ukrainu. Naukova dumka, Kiiv, 8(4) (1982) 19-23. 